\title{
Ravishment, Legal Narratives, and Chivalric Culture in Fifteenth-Century England
}

\author{
Shannon McSheffrey and Julia Pope
}

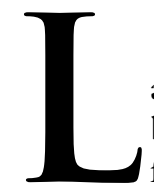

ate medieval English legal definitions of ravishment are puzzling to us, both because they conflated categories we would think of as separateforced coition, abduction, and elopement - and because both the law on abduction and rape and its application in practice were confusing and inconsistent. ${ }^{1}$ Even the word "ravishment" and its verbal forms, along with the Latin raptus, were used to mean what seem to us quite different things: ravishment could mean abduction or taking away with no sexual violation implied-children could be ravished by parents in custody disputes, for instance, and thieves could ravish goods. It could also, however, denote or imply the carrying away of a woman in order to violate her sexually, what we would call rape, often (but not always) in the context of a coerced marriage. ${ }^{2}$ As literary scholars have noted, literary de-

Shannon McSheffrey is professor of history at Concordia University. Julia Pope holds an MA from Concordia University and is currently working toward a degree in archival studies at Wayne State University. From 2003 to 2005 she was an associate editor at the Records of Early English Drama project at the University of Toronto. The authors would like especially to thank Caroline Dunn for her generous help, as well as Stephen Chrisomalis, Katherine French, Eric Reiter, Anna Clark, and the anonymous readers for $J B S$.

${ }^{1}$ Two recent works survey the voluminous literature on abduction and ravishment: Caroline S. Dunn's recent thesis, now the most complete study of abduction, "Damsels in Distress or Partners in Crime? The Abduction of Women in Medieval England" (PhD diss., Fordham University, 2007); and Jeremy Goldberg, Communal Discord, Child Abduction, and Rape in the Later Middle Ages (New York, 2008), $161-71$.

${ }^{2}$ See the Middle English Dictionary (MED; http://quod.lib.umich.edu/m/med/), s.vv. "ravish(e)ment" (n.) and "ravishen" (v.; with the illustrative quotations); the Oxford English Dictionary, s.v. "ravish" (v.), esp. $2 \mathrm{a}$ and $2 \mathrm{~b}$; and for a few further examples associating ravishment and sexual violation, Chris Given-Wilson, ed., The Parliament Rolls of Medieval England (PROME) (Leicester, 2005), 5:15, 5: 462, 6:240. Henry Ansgar Kelly has argued that ravishment and raptus were confined to nonsexual meanings in the late Middle Ages; see Kelly, "Meanings and Uses of Raptus in Chaucer's Time," Studies in the Age of Chancer 20 (1998): 101-65, and "Statutes of Rape and Alleged Ravishers of Wives: A Context for the Charges against Thomas Malory, Knight," Viator 28 (1997): 361-419. While clearly the words did not always connote sexual violation, in other instances they also clearly did (as in the citations above, esp. the quotations in the $M E D$, and in the scholarship referenced in nn. 1 and 3 ).

Journal of British Studies 48 (October 2009): 818-836

(C) 2009 by The North American Conference on British Studies.

All rights reserved. 0021-9371/2009/4804-0001\$10.00 
pictions of rape and ravishment, especially in the romance genre, worked in complicated relationship with the sometimes confused and confusing legal definitions. ${ }^{3}$

In this article, we reflect on the relationship between chivalric and legal narratives of ravishment, focusing on a particular case from Norfolk in the 1450s. The narratives in the legal documents for this case, as in other rape and abduction accusations, were shaped according to statutory definitions of ravishment-indeed details may have been altered or entirely invented in order to fit the legal requirements of prosecution under the relevant statutes. ${ }^{4}$ But, even in the indictments and other documents introduced in the courts that considered this case, the meanings of ravishment were not confined to the letter of the law; they also derived from cultural understandings of ravishment in the world of chivalry and romance. Using approaches pioneered by Natalie Zemon Davis, we will examine the legal records as cultural productions, as narratives influenced by the imbrication of law and culture, rather than as straightforward accounts of an event. ${ }^{5}$ Indeed, we want to push this further to argue that the intertwining of law and chivalric culture went beyond the pages of the romance and the legal documents, that the culturally available narratives of ravishment shaped both action and sexual desire. Together, these three strands-law, chivalric culture, and social practice-were all implicated in the phenomenon of ravishment, both in the way actual instances unfolded and as people understood it and narrated it. The strands formed a feedback loop, each playing into and reinforcing the others, making untangling their implications challenging.

The focus of our analysis will be a vivid story of a ravishment in Norfolk in the early 1450s, preserved in the records of the Court of King's Bench and in a letter written by John Paston I. ${ }^{6}$ According to those records, a gentleman named Robert Langstrother, together with a large party of armed men, burst into Edmund Wichingham's manor house in Wood Rising, Norfolk, and feloniously ravished Jane,

${ }^{3}$ Kathryn Gravdal, Ravishing Maidens: Writing Rape in Medieval French Literature and Law (Philadelphia, 1991); Corinne Saunders, Rape and Ravishment in the Literature of Medieval England (Cambridge, 2001), and "A Matter of Consent: Middle English Romance and the Law of Raptus," in Medieval Women and the Law, ed. Noël James Menuge (Woodbridge, 2003), 105-24; Louise M. Sylvester, Medieval Romance and the Construction of Heterosexuality (New York, 2008); Kim M. Phillips, "Written on the Body: Reading Rape from the Twelfth to the Fifteenth Centuries," in Menuge, ed., 125-44. Other scholars have also noted the constructed nature of legal narratives of rape: see Barbara A. Hanawalt, "Whose Story Was This? Rape Narratives in Medieval English Courts," in her "Of Good and Ill Repute": Gender and Social Control in Medieval England (New York, 1998), 124-41; and Kim M. Phillips, "Four Virgins' Tales: Sex and Power in Medieval Law," in Medieval Virginities, ed. Anke Bernau, Ruth Evans, and Sarah Salih (Cardiff, 2003), 80-101, esp. 81-86.

${ }^{4}$ On the importance of the law in the framing of the narratives, see Anthony Musson, "Crossing Boundaries: Attitudes to Rape in Late Medieval England," in Boundaries of the Law: Geography, Gender and Jurisdiction in Medieval and Early Modern Europe, ed. Anthony Musson (Aldershot, 2005), 84-101; Dunn, "Damsels," 9, 32-33; Goldberg, Communal Discord, 35-42, 44.

${ }^{5}$ Natalie Zemon Davis, "Note critique: Les conteurs de Montaillou," Annales: Économies, Sociétés, Civilisations 34, no. 1 (1979): 61-73, and Fiction in the Archives: Pardon Tales and Their Tellers in Sixteenth-Century France (Stanford, CA, 1987).

${ }^{6}$ The King's Bench records are at Coram Rege Roll, Michaelmas 1451, the National Archives (TNA): Public Record Office (PRO) Court of King's Bench (KB) 27/762, rex mm. 1, 5, 19d; Coram Rege Roll, Easter 1452, TNA: PRO KB 27/764, rex m. 6, plea m. 28d; TNA: PRO KB 27/765, plea m. 48; Coram Rege Roll, Trinity 1452, TNA: PRO KB 27/766, rex m. 32d. The bill drafted by Paston is in Norman Davis, ed., The Paston Letters and Papers of the Fifteenth Century, 2 vols. (Oxford, 1971, 1976), 1:69-71. 
one of Wichingham's daughters and heiresses. The accounts of the ravishment are dramatic enough that the case has been presented by a number of historians as illustrative of the practice of ravishment among the English gentry in the fifteenth century. ${ }^{7}$ The story itself has struck those scholars as particularly compelling, illustrating for them the "tribulations" and "heartrending" suffering caused by fortune-hunting men snatching nubile heiresses against their wills. ${ }^{8}$ As we will argue below, however, any interpretation of the records related to this case must recognize that the story was designed to be compelling, the gripping details deliberately rather than artlessly told. ${ }^{9}$ As Malcolm Gaskill has suggested, it is most useful to think of the participants in the legal process as "engaged in a common discourse whereby truth was crafted as much as discovered"-indictments, statements, and witness testimony were meant to persuade, both legally and culturally, rather than just to tell the facts. ${ }^{10}$ The legal narrative in the records that directly recount the ravishment, the long and detailed indictments of Langstrother and his alleged accomplices recorded at King's Bench, and a draft bill concerning the case written by John Paston do not directly tell us what happened on that June day in 1451-as close analysis shows, the stories are partial and inconsistent and possibly partly or wholly invented-but rather what the composers of those documents wanted or needed their readers to think had happened. While the narratives submitted to or drafted for the courts were framed at least partly to conform to legal definitions of ravishment in English statute law, they also drew upon more diffuse cultural understandings of ravishment drawn from chivalric culture and aristocratic conceptualizations of marriage, sex, and gender. While such an analysis calls into question our ability to know what happened at Edmund Wichingham's manor house in June 1451, it can give us a much richer understanding of the complicated relationships between legal processes and the broader cultural contexts in which law was waged.

The accounts of the ravishment of Jane, daughter of Edmund Wichingham,

${ }^{7}$ Roger Virgoe's article "The Ravishment of Jane Boys," in East Anglian Society and the Political Community of Late Medieval England (Norwich, 1997), 151-58, has been tremendously helpful for us and may be consulted for further details on the legal processes. Caroline Dunn's discussion, although short, is sure-footed, if less skeptical about the records than we are ("Damsels," 229-32, 246-47). Helen Castor's recent book briefly retells the story as in Paston's letter and the King's Bench records (Blood and Roses: One Family's Struggle and Triumph during the Tumultuous Wars of the Roses [New York, 2007], 124-25). A number of other scholars have drawn their accounts of the case from John Paston's letter alone. John Bellamy discusses the abduction in his Criminal Trial in Later Medieval England: Felony before the Courts from Edward I to the Sixteenth Century (Toronto, 1998), 173; Philippa Maddern discusses it in Violence and Social Order: East Anglia, 1422-1442 (Oxford, 1992), 101; Emma Hawkes uses Paston's letter to lead into a broader discussion of issues of consent in abduction in "'She was ravished against her will, what so ever she say': Female Consent in Rape and Ravishment in LateMedieval England," Limina: Journal of History and Cultural Studies 1, no. 1 (1995): 47-54. Colin Richmond's The Paston Family in the Fifteenth Century: The First Phase (Cambridge, 1990) mentions the letter only briefly (on 142) and does not subject it to any analysis. Our reading of the letter differs in various ways from these previous interpretations of the case.

${ }^{8}$ Bellamy, Criminal Trial, 173; Maddern, Violence, 101. Castor, Blood and Roses, 124, illustrates how easily the fifteenth-century narrative translates into twenty-first-century bodice-ripper clichés: "Whether he was driven by love for Jane or lust for her riches, Langstrother knew that he had missed his chance as a suitor, but could not bring himself to take no for an answer."

${ }^{9}$ For a similar point regarding church court depositions, see Goldberg, Communal Discord, 37.

${ }^{10}$ Malcolm Gaskill, Crime and Mentalities in Early Modern England (Cambridge, 2000), 27. 
derive from a number of different sources. Those sources convey roughly the same story, but when the narratives are disaggregated and examined separately, we see that they emphasize different aspects of the story, each reflecting the different legal purposes for which the narratives were prepared.

The first, and most detailed, of these sources are the indictments of the accused ravishers, recorded at the Court of King's Bench in Michaelmas term, 1451. ${ }^{11}$ Those indictments originated when Robert Langstrother and eighteen other men were brought up before the commission of the peace at Norwich on 22 June 1451 on felony charges of ravishment, presumably (although, as was common, not explicitly) under the 1285 Statute of Westminster. ${ }^{12}$ The statutory basis of the charges is crucial, as in 1451 two main statutory bases existed for the launch of a ravishment case, and in each of these the definition of ravishment, and in particular the role of the woman's consent in the deed, differed. By the 1285 Statute, the ravishment of any woman without her consent was a felony punishable by death. ${ }^{13}$ In order to make a felony case, it was crucial to emphasize the woman's unwillingness to be seized, which the indictment of Langstrother and the others did in a number of different ways. ${ }^{14}$

According to the indictment, which was written in Latin but interspersed with English quotations, at five o'clock in the afternoon on 8 June 1451, an armed party of as many as sixty men rode up to Edmund Wichingham's manor house in Wood Rising, Norfolk, intending to ravish Jane, one of Wichingham's daughters and heiresses. Arrayed in a warlike manner, bearing swords, bows and arrows, glaives, lances, and light body armor, the party burst into the hall of the manor house, their weapons drawn. In the hall they found Wichingham's wife Alice and her mother sitting down to an evening meal, Wichingham himself being away from home on that day. The leader of the armed party, the gentleman Robert Langstrother, unsheathed his sword and demanded of Alice Wichingham, "Deliuer me thy doughter." Seeing that Jane was not at the table with her mother, he threatened a female servant, his sword at her breast: "tell me where this gentilwoman is and elles y shall steke the to the hert with this suerd." Langstrother and his men found Jane in an adjoining chamber and seized her. When Langstrother and his henchman began to drag her away, Jane resisted "as much as she could [pro posse suo]." She also cried the hue (a crucial ingredient of a felony indictment), as they laid hands on her and dragged her away violently, and insistedfutile though her defiance was, surrounded by dozens of armed men-that she would never go with them and would never "consent to [marry] Robert Langstrother." As they left the house, Langstrother's henchmen nearly killed a servant,

${ }^{11}$ Coram Rege Roll, Michaelmas 1451, TNA: PRO KB 27/762, rex mm. 1, 5, 19d.

${ }^{12}$ The 1285 Second Statute of Westminster (Statutes of the Realm, 10 vols. [London, 1963], 1: 87-88) governed felony prosecutions of ravishment; on prosecutions under the statute, see Dunn, "Damsels," chap. 1; Kelly, "Statutes," and "Meanings."

${ }^{13}$ Statutes of the Realm, 1:87-88; Dunn, "Damsels," chap. 1, esp. 51-53, 66-67.

${ }^{14}$ A number of scholars have asserted that the consent of the victim was largely irrelevant in the prosecution of fourteenth- or fifteenth-century ravishment cases (e.g., Saunders, "Matter of Consent," 105-6, 124; Goldberg, Communal Discord, 164-66; Hawkes, "She was ravished," 48, 51; Musson, "Crossing Boundaries," $97 \mathrm{n} .8$ ). The focus on the (lack of) consent of the victim in the case under consideration here suggests that at least in the mid-fifteenth century those who framed the legal submissions were very attentive to this aspect of the statutory definition of ravishment. 
William Vyrly, by wounding him with a lance and shooting him with three arrows; Vyrly's life was saved only because he happened to fall into a clay pit. Langstrother and his men violently tied Jane by her arms and legs to the horse of one of the armed men and rode away with her. The indictment's narrative ends with the ravishers and their victim being received at Carbrook, a preceptory (religious house) of the Hospitaller Order, by Robert's relative the Hospitaller William Langstrother. The Jane of the indictment, the innocent daughter of a gentleman treated roughly and rudely by Langstrother and his fellows, was constant in her resistance, demonstrating clearly the felony of ravishment and the central role of the woman's consent in the definition of that felony. ${ }^{15}$

Other legal actions taken in the case had a different statutory underpinning and thus produced somewhat different narratives. Perhaps because it seemed likely that the felony indictment was going to fail — as it eventually did, all the accused being acquitted by early 1453-Edmund Wichingham launched an action on the civil side of King's Bench on 10 May 1452, this time under the Statute of 6 Richard II (1382). ${ }^{16}$ This statute allowed an action of trespass to be undertaken by the ravished woman's family, rather than only by royal suit, even if the ravished woman subsequently consented to the ravishment. ${ }^{17}$ In the record of Wichingham's suit, the recorded details of the alleged ravishment were sparse. Much more laconically than in the felony indictment, Wichingham alleged that one of his daughters and heirs, Jane, was at Wood Rising, "in God's peace and the king's [in pace dei et domini regis]," when at five in the afternoon Robert came and "ravished [rapuit]" Jane, feloniously and with premeditation. This allegation was followed by a crucial element of the story that had been omitted from the original felony indictment, which indicates why the 1382 Statute was invoked in this second attempt to pursue Langstrother: Wichingham's bill revealed that eight days following the ravishment, on 16 June 1451, Jane "consented to [marry] Robert, utterly refusing to have him punished for the ravishment according to the law." 18 Robert Langstrother appeared to answer to the suit and wholly denied the allegations. A jury was summoned to hear the case on 4 July 1452, but the King's Bench records do not indicate the outcome.

Although the King's Bench records for Wichingham's suit give us only bare

${ }^{15}$ Coram Rege Roll, Michaelmas 1451, TNA: PRO KB 27/762, rex m. 1.

${ }^{16}$ Coram Rege Roll, Michaelmas 1451, TNA: PRO KB 27/762, rex mm. 1, 5, 19d.; Coram Rege Roll, Easter 1452, TNA: PRO KB 27/764, plea m. 28d.

${ }^{17}$ Statutes of the Realm, 2:27; Dunn, "Damsels," 54-55; J. B. Post, "Sir Thomas West and the Statute of Rapes, 1382," Bulletin of the Institute of Historical Research 53, no. 127 (1980): 24-30. The 1382 Statute also allowed for cases to be tried as felonies. We have emphasized the sequential nature of the consent more than Post, who underplays the word "post" in the 1382 Statute clause "post huiusmodi raptum huiusmodi Raptoribus consenserint" (Statutes of the Realm, 2:27; our emphasis) - stating instead that the statute applied to women "regardless of the woman's consent" rather than only to those who consented subsequently (Post, "Sir Thomas West," 27). This, however, is not our reading of the statute or its application in the case under consideration here. The 1285 Statute had also allowed for prosecution "although the woman consent after" but only at the suit of the king (Statutes of the Realm, 1:87). See also Kelly, "Statutes," 371-73.

18 "Post quem quidem raptum sic perpetratum videlicet die mercurii proximo post festum predictum eadem Johanna eidem Roberto apud Wygenhale beate Marie Magdalene in comitatu Norff' predicto de perpetracione eiusdem raptus consentiret, eundem Robertum pro eodem raptu secundum iuris exigenciam punire omnino recusando" (Coram Rege Roll, Easter 1452, TNA: PRO KB 27/764, plea m. 28d). 
bones-Jane was feloniously ravished, and then subsequently she consented-a draft of a letter regarding the case survives among the Paston letters. Although the letter is imprecisely dated, John Paston I almost certainly wrote in the context of this trespass suit, possibly immediately before the case was to be put to the jury in early July. ${ }^{19}$ Paston addressed his letter to Richard Southwell, who was both one of Wichingham's pledges in the suit and, perhaps even more importantly, the man whom her father had intended her to marry, at least before the ravishment. Paston wrote to offer Southwell the latest news about the case and advice about what tactics remained to be pursued. Paston told Southwell that he had, the week before, spoken to Wichingham in London. Although they were pleased that the duke and duchess of Norfolk were working to support their case, all was not going well. Wichingham had submitted a bill to "the Lords"-either the king's council or perhaps the justices in King's Bench-asking for Jane to be delivered into his custody immediately and that her accused abductors be arrested. ${ }^{20}$ This was the situation when Paston left London for Norwich, but since then he had had news from London. Rather inconveniently, Jane had herself appeared before the Lords and contradicted her father, presumably affirming that she had gone willingly with her abductor, Robert Langstrother. This would have made the legal grounds for prosecution under the 1382 Statute shaky, as a remedy was available for cases in which the woman consented subsequently-but by implication there was no trespass in cases in which the woman was complicit in the ravishment itself. Paston commented that Jane did not know her own best interests; by doing this she had only "mescheue[d] her-selff," as he put it. Nonetheless, it was important, Paston thought, for Southwell to pursue the matter, not for her sake but both to uphold "the worchepe" (maintain the credibility) of those who had worked hard to arrange her marriage to Southwell and for the sake of "ponyshing . . . the gret oryble dede" that her abductor has committed. With that in mind, Paston employed his considerable legal acumen and experience to draft for Southwell and Wichingham "dyuers articljs in a bill closed herin wheche preue that she was raveshid ayens hyr wel, what so ever she sey." 21

${ }^{19}$ We broadly accept Norman Davis's dating of the letter to July 1452, with the small correction to the specific date (which he gives as 20 July). Davis's assignment of the year to 1452 , based on intertextual evidence in the letter collection, also fits the chronology we can establish from the King's Bench records. By reference to the King's Bench records, however, we prefer the date 2 July 1452 . The letter is dated "pe Soneday nex before pe fest of Sent Margare[t]." There were two feasts of (two different) St. Margarets, 8 July and 20 July. In the first case, the prior Sunday in 1452 was 2 July; in the second case, it was 16 July. Given that the jury had been summoned to hear the trespass case on 4 July, it appears more probable that the letter was written just before that, on 2 July. Davis, Paston Letters, 1: $69-71$.

${ }^{20}$ Virgoe understands "the Lords" to be the King's Council (Virgoe, "Ravishment," 155), and this is certainly plausible. In another alleged abduction, the victim appeared before the king's council "in the chamber of the parliament" requesting assistance against her abductor. Anne Curry, "Henry VI: Parliament of January 1437, Introduction," in PROME, citing TNA: PRO Records of the Exchequer (E) 28/58/60; a petition regarding the case was later presented by the commons: PROME, 4:497.

${ }^{21}$ Davis, Paston Letters, 1:70. On Paston's legal training, see Helen Castor, "Paston, John (I) (1421-1466)," in Oxford Dictionary of National Biography, ed. H. C. G. Matthew and Brian Harrison (Oxford, 2004), http://www.oxforddnb.com/view/article/21511. For his experience working as Sir John Fastolf's right-hand man, see Richmond, Paston Family: First Phase, chap. 7; Colin Richmond, The Paston Family in the Fifteenth Century: Fastolf's Will (Cambridge, 1996), chap. 3, and The Paston Family in the Fifteenth Century: Endings (Manchester, 2001), 4-5. Edmund Wichingham himself was also an active lawyer; Virgoe, "Ravishment," 151. 
There followed a series of "prouis" that Jane had been "rauischid ageyn her wil, and not by her own assent." At the time of her taking, Jane called her abductor "knave" and "false traitor" and wept and cried out piteously. ${ }^{22}$ Langstrother and his men tied her to a horse to carry her off, but she fell off as they began to ride away. As she was tied up again, Jane once more reviled Langstrother. As Langstrother, his men, and the horse carrying Jane began to ride off again, Jane's mother ran after them, until she could run no more. When her mother fell back, Jane cried to her and said that whatever happened she "shuld neuer be weddyd to that knave, to deye for it." ${ }^{23}$ As she rode with the abductors she cried out to anyone she saw along the way, letting everyone know whose daughter she was and how she had been ravished against her will. Later, in confession, she told the priest that she would rather die than be married to Langstrother, which in turn caused the priest to declare that he would not marry them, even for a thousand pounds. To underline Jane's unwillingness to be taken by Langstrother, Paston added that before the ravishment Jane had sent many tokens to Southwell, showing that she did not love Langstrother. Indeed Langstrother was clearly not in her confidence, as he had sent "spyes" to her house, or at least one man from the Hospitaller preceptory at Carbrook, who had come repeatedly to Wood Rising to ask Jane's maidservant whether she had made a marriage contract with Southwell. ${ }^{24}$ Although Langstrother obviously had had designs on Jane, she did not reciprocate.

In his draft bill, Paston emphasized Jane's lack of consent at the time of the ravishment. In order to combat Jane's own claim that she had consented to the ravishment, that it was in fact an elopement rather than an abduction, Paston suggested that Wichingham and Southwell argue what the 1382 Statute allowed them to argue: that her word regarding her consent could not be accepted, colored as it was by her subsequent change of mind. No matter what she said now, at the time she resisted vehemently, and here are the "proofs." ${ }^{25}$ While we have no details regarding the narrative that Jane told when she appeared before the Lords, her story, too, may have hit the right legal notes: she apparently told them that she had consented all along, undercutting the grounds on which prosecution could take place under the 1382 Statute. In other words, in the narratives in the indictments enrolled in the King's Bench, in Paston's draft bill, and in Jane's own statement, the "facts" were shoehorned into particular legal forms.

The 1382 Statute left a loophole for families to slip through when their young women eloped with unsuitable men: a woman's testimony that she had consented to a ravishment could be countered by claims that at the time of the ravishment itself she had vociferously objected, and thus she had been coerced or seduced into consenting only afterward. Paston advised Southwell and Wichingham to try this argument - as Paston put it so neatly, Jane "was raueshid ayens hyr wel, what so ever she sey." ${ }^{26}$ But while the statute made this argument legally possible, and thus from Paston's point of view probably worth a shot, it is not clear that this kind of claim was very successful as a legal strategy when a woman was adamant

\footnotetext{
22 Davis, Paston Letters, 1:70.

${ }^{23}$ Ibid.

${ }^{24}$ Ibid.

${ }^{25}$ Ibid.

${ }^{26} \mathrm{Ibid}$.
} 
that she had consented all along. In one Chancery case, for example, Agnes Umfrey's insistence under examination that she had fully consented to an alleged ravishment apparently torpedoed a ravishment prosecution. ${ }^{27}$ Although some twentieth- and twenty-first-century historians have accepted the story of the indictment and the draft bill, it is likely that the Court of King's Bench found Jane's tale-whatever it was-more convincing. The lack of further records regarding Wichingham's civil suit in King's Bench suggests that the case was abandoned, perhaps precisely in the face of Jane Boys's insistence that she had gone willingly. The subsequent acquittal of Robert Langstrother and the other men indicted for the ravishment when the case came up at the Norfolk peace sessions in January 1453 , with no evidence being produced by the prosecution, suggests similarly that Wichingham and his associates had elected not to pursue the case any further. ${ }^{28}$

Jane Boys and Robert Langstrother established a lasting marriage. ${ }^{29}$ Even more interesting, the couple apparently reconciled with Jane's father by 1454 , judging by legal actions they undertook in concert. Edmund Wichingham worked together with Robert and Jane Langstrother in legal battles in Chancery against Robert Boys's family and their circle over Robert Boys's will and the provisions it had made for Jane and her daughter. ${ }^{30}$ Although by the 1382 Statute, Edmund Wichingham could have disinherited Jane, and may have done so (there is no evidence one way or the other), this seems unlikely given their reconciliation. ${ }^{31}$ And indeed even the Wichingham family connection with Robert Southwell, Jane Boys's original intended husband, was salvaged in the end; he went on to marry Jane's younger sister Anne, becoming brother-in-law to Jane and Robert Langstrother. ${ }^{32}$ Wichingham may have been more easily reconciled to his older daughter's choice by the recovery of the original marital alliance-as often in these late medieval marriage arrangements among the elite, the daughters were effectively interchangeable. Wichingham may also have come to agree that the marriage to Robert Langstrother had much to recommend it. Although we have been able to uncover little about Robert Langstrother himself, he was the brother of Sir John Langstrother, a prom-

\footnotetext{
${ }^{27}$ Deposition of Isabel Umfrey, ca. 1432-43, TNA: PRO Early Chancery Proceedings (C) 1/9/199. ${ }^{28}$ Coram Rege Roll, Michaelmas 1451, TNA: PRO KB 27/762, rex m. 1d.

${ }^{29}$ They were still married in 1463 when Robert died (will of Robert Langstrother, 1463, TNA: PRO Prerogative Court of Canterbury [PCC], Prob. 11/5, fol. 10r).

${ }^{30}$ See esp. Edmund Wychyngham, esq., feoffee of Robert Boys v. Edmund Blake, esq., ca. 1455-56, TNA: PRO C $1 / 25 / 204$, a Chancery bill dated $1455-56$ but which indicates that Wichingham was already involved in litigation over the Boys inheritance in 1453-54. Slightly complicating this picture is Robert Langstrother, esq., Joan his wife, and Katherine Boys v. Robert Ingelous, esq., John Heydon, and Edmund Wychyngham, feoffees of Robert Boys, esq., ca. 1455-56, TNA: PRO C 1/25/157, in which Robert and Jane Langstrother and Jane's daughter Katherine Boys sue Robert Boys's feofees, including Edmund Wichingham, to get access to the Boys lands. The answer (TNA: PRO C 1/25/ 157b) of John Heydon, one of those feoffees, to the Langstrothers' bill, however, indicates that the delay in handing over the lands is due to Edmund Blake's claim that he holds the lands in question, which the feoffees themselves dispute. TNA: PRO C 1/25/204, brought by Edmund Wichingham, is directed against Blake. Behind this set of Chancery bills-and not strictly relevant to our argument here-lie the actions of Robert Boys's mother, Dame Sybil Boys, who appears to have seized the opportunity that her son's death presented to manipulate his will, seize his lands, and sell them off to Edmund Blake. On the interesting Sybil Boys, see Richmond, Paston Family: Fastolf's Will, 9-11.

${ }^{31}$ As Dunn remarks, discussing the Boys case specifically, she has found no such examples of disinheritance following the 1382 Statute ("Damsels," 231).

${ }^{32}$ Richmond, Paston Family: First Phase, n. 142.
} 
inent Hospitaller and later prior of the order in England. ${ }^{33}$ Sir John Langstrother played a prominent role in the turbulent politics of the 1450s and 1460s, affiliated, albeit at a higher level, with the same Lancastrian orbit as the Pastons and their associates, including Wichingham. (The Pastons were faithful followers of the Earl of Oxford, if perhaps not entirely Lancastrian per se. $)^{34}$ Faced with the fait accompli of the ravishment and subsequent marriage, Wichingham may have chosen to see the bright side.

The surviving evidence of the circumstances surrounding the marriage of Jane Boys and Robert Langstrother is thus contradictory. While her father and his friends alleged that she had been violently ravished by Langstrother and unaccountably refused to participate in his prosecution, she herself appears to have denied this story, and we can infer from Paston's letter and the records of her father's suit in the King's Bench that she claimed that she had consented all along. It is possible that the events of 8 June 1451 occurred as described in the indictment and Paston's letter but that Jane subsequently changed her mind, either through a form of seduction or resignedly, recognizing her limited options. Most previous scholars who have studied this case in any detail have followed this latter line, understanding the account Paston gives in the bill as an accurate depiction of the events in question and indeed as an illustration of the situation the 1382 Statute was meant to remedy (in which a family could prosecute a ravishment without the alleged victim's cooperation, in a case in which the victim subsequently consented). Roger Virgoe's account, for instance, suggests a form of Stockholm Syndrome: as he puts it, Jane "seems to have been won over by Robert" in the days following the ravishment itself. ${ }^{35}$ For Helen Castor and Philippa Maddern, the story serves as an example of the extremely restricted choices an abducted woman had in such circumstances: as Maddern suggests, Jane's subsequent consent may have derived from her recognition that the alternative-at best being rendered back to her father in a defiled and unmarriageable state-was worse than simply accepting the ravisher as her husband. ${ }^{36}$ This is a plausible reading of the narrative that Paston tells, a credible assessment of the choices facing a ravished woman given the complicated interrelationship among gender, violence, and sexuality. Yet in this particular case it does not take sufficiently into account that the narrative is not an illustration of the "subsequent consent" scenario set out in the 1382

\footnotetext{
${ }^{33}$ Although the indictments in King's Bench in the fall of 1451 regarding the ravishment several times identify Richard's Hospitaller relative William Langstrother as "the confrère of Robert Langstrother's brother, the prior of St. John of Jerusalem in England" "Willelmus Langstrother confrater fratris Roberti prioris sancti Johannis de Jerusalem in Anglia in London," Coram Rege Roll, Michaelmas 1451, TNA: PRO KB 27/762, rex m. 5; see also mm. 1, 19d), other sources indicate that Sir John Langstrother became prior only in 1469 (although he held a number of key positions, including receiver of the treasury of the order, from the 1440s). R. A. Griffiths, "Langstrother, Sir John (d. 1471)," in Matthew and Harrison, Oxford Dictionary of National Biography; Gregory O'Malley, The Knights Hospitaller of the English Langue, 1460-1565 (Oxford, 2005), 127-31, 351. At the time of the ravishment, William Langstrother was preceptor of Eagle (Lincolnshire; O'Malley, Knights Hospitaller, 351 ), and the King's Bench indictments suggest that he was also preceptor of Carbrook, another Hospitaller preceptory. Sir John Langstrother and Jane are named as the executors of Robert Langstrother's will (TNA: PRO PCC, Prob. 11/5, fol. 10r).

${ }^{34}$ See Richmond, Paston Family: Endings, 6-8.

${ }^{35}$ Virgoe, "Ravishment," 151.

${ }^{36}$ Maddern, Violence, 101; Castor, Blood and Roses, 125.
} 
Statute but a legal argument, a demonstration that the case fits the legal requirements of the 1382 Statute. It seems most likely to us that the events of 8 June as described in the indictment and the bill annexed to Paston's letter were wholly invented or at least significantly misrepresented and that instead Jane eloped with Robert Langstrother. Caroline Dunn has suggested a third, and intriguing, possibility - that this case involved a staged ravishment. She believes that the events may have unfolded roughly as described in the documents but that Jane was complicit all along. ${ }^{37} \mathrm{We}$ will explore this third possibility further below.

Close readings of the legal submissions for the alleged ravishment indicate that, at a minimum, the evidence was massaged, if not completely fabricated, in order to create a compelling case. The two narratives we have in detail-the original indictment and Paston's bill—not only accurately hit the legal marks, but they also attempted to persuade through what we might call paralegal details. For instance, in the original indictment and throughout the King's Bench records on the case, Jane's full name and marital status are never mentioned. She is first identified as "Jane, daughter and co-heiress of the aforesaid Edmund [Wichingham]." 38 Throughout the indictment, she is described as "Johanna filia." On the one hand, the qualifier "filia," daughter, distinguishes Jane from her grandmother, also named Johanna or Joan/Jane. But, on the other, the repeated use of the word "filia" in relation to Jane-in parts of the story where there was no possibility that a reader or listener would be confused about which Johanna was meant-also underscores her relationship to her parents, particularly her father, and is likely to have implied to the indictment's audience both youth and maidenhood. At the time of the ravishment, however, Jane was not a maiden but a widow and a mother, and her surname was that of her deceased husband, Robert Boys. It is probable that this implication-that Langstrother had not only ravished a woman but had deflowered a maiden - was meant to strengthen the sense of outrage that pervades the indictment's tone. ${ }^{39}$ Although Jane Boys's marital status was not, strictly speaking, legally relevant to the charge of ravishment, revealing Jane Boys's widowed state would have disturbed the narrative of defilement implied by the indictment. ${ }^{40}$ It could also have raised the possibility that, as a widow, Jane was much more likely to play an autonomous role in choosing a subsequent marriage partner and was much less likely to be the compliant and obedient daughter of the indictment. ${ }^{41}$

While the original indictment left its readers simply to infer that Jane was a young, dependent, and never-married daughter of Edmund Wichingham, Paston's draft bill took a slightly different tack on this question, probably because Jane's widowed state had been revealed by that point in the King's Bench proceedings.

\footnotetext{
${ }^{37}$ Dunn, "Damsels," 229-32, 246-47.

38 "Johannam filiam et vnam heredum predicti Edmundi," Michaelmas 1451, TNA: PRO KB 27/ 762 , rex m. 1 .

${ }^{39}$ See Phillips, "Written on the Body," 131-33, regarding the rhetorical power of allegations of violating the virginal body in rape pleas.

${ }^{40}$ The 1285 Statute explicitly included married women and widows as well as maidens under its purview (Statutes of the Realm, 1:87-88). Dunn, however, notes that the forcible abduction of widows was an issue causing concern in the mid-fifteenth century ("Damsels," 148-57).

${ }^{41}$ See Barbara J. Harris, English Aristocratic Women, 1450-1550: Marriage and Family, Property and Careers (Oxford, 2002), 165-66.
} 
The heading of Paston's bill identified her squarely by her married name- "pes be the prouis that Jane Boys was rauischid ageyn her wil, and not be her own assent"-but he continued in the bill to stress her dependence on her parents and her compliance to their desires and plans. ${ }^{42}$ This emphasis is at odds with his comments about her in the text of the letter that precedes the bill. Indeed, perhaps the strongest evidence for the at least somewhat fictive nature of the bill appended to Paston's letter is the contrast between the two Janes, the Jane of the letter text and the Jane in the bill. In the bill, Jane is constructed as a woman who reviles those who have committed this offense against her father's daughter and who very properly loves the man whom her father has chosen for her; the Jane of the letter, however, is an ungrateful daughter who has foolishly chosen to disparage the plans her father and his friends have made.

In addition to this evidence for the constructed nature of the narrative of Jane Boys's ravishment told in the records of the Court of King's Bench and Paston's letter, other legal records recounting ravishments around the same time have a number of suspiciously similar details. This suggests that Paston and the framers of the original indictment adapted details they came across in London legal circles or even that their own formulations of the Jane Boys ravishment came to be employed by others. Clearly credible-sounding circumstantial details-and the more spurious the claims were, the more credible those details needed to berendered petitions against wrongdoers more convincing.

One detail featured in the Boys ravishment narrative-Jane being forcibly set upon a horse, then falling off it and being tied back on-has been termed by Jeremy Goldberg "the archetypical forced abduction motif." ${ }^{43}$ As Goldberg has pointed out, fourteenth-century ravishment narratives frequently featured a scene in which the ravished woman was carried off on a horse, held on to the animal either by one of the ravishers or, as in one case, "laid crossways 'like a sack." "44 Several fifteenth-century ravishment narratives also employed details regarding the victim's being forcibly borne away on a horse. Joan Beaumont's son and second husband petitioned Parliament in March 1453, for instance, to complain of her ravishment by Edward Lancaster in October $1452 .{ }^{45}$ Although most of the narrative is quite different from the Boys ravishment, there is considerable congruence in details about taking the victim away by tying her to a horse with a piece of cloth. ${ }^{46}$ The employment of the getaway horse served several functions in a legal ravishment narrative. First, both the victim's powerlessness and her unwillingness to be taken could be neatly illustrated by being bound to a horse and swiftly borne

\footnotetext{
${ }^{42}$ Davis, Paston Letters, 1:70.

${ }^{43}$ Ibid.; Goldberg, Communal Discord, 166.

${ }^{44}$ Goldberg, Communal Discord, 137-38.

${ }^{45}$ PROME, 5:269-71.

${ }^{46}$ Our attention to the Beaumont case was first drawn by the early editor of the Paston Letters, James Gairdner, who also notes the similarity between the allegations in the Beaumont and Boys cases but goes no further with this observation than suggesting, then rejecting as impossible, that they could be the same women and the same case. James Gairdner, ed., The Paston Letters, 6 vols. (repr., Gloucester, 1986), 4:260. Also similar, but not identical, is the role of the priest who is being pressured to marry the couple (in Jane Boys's case, the priest withstands the pressure; in Joan Beaumont's case, he gives in to it).
} 
away, all the while crying piteously. ${ }^{47}$ Second, it was credible: an aristocratic ravisher wishing to carry away a woman speedily would naturally have used a horse.

Jane's crying and weeping also bears general resemblance to the descriptions of ravishments in Chancery bills. In one case, for instance, datable between 1456 and 1460 (thus after the Boys case), two young Sussex heiresses, Margaret and Elizabeth Wakehurst, were allegedly ravished by their step-uncles Nicholas and Richard Colepepir, the brothers of their mother's second husband, Sir John Colepepir. ${ }^{48}$ As their grandmother and her supporters claimed in their petition, "the seide Margarete and Elisabeth at the tyme of their takyng away [made] grete and pittious lamentacion and wepyng," crying "pittiously" for their mother as they were borne away to Kent and thence to London "with force and armes." Both Margaret and Elizabeth went on to have long and apparently affectionate marriages with their abductors. Although the girls' grandmother Elizabeth continued to make life difficult for the couples with continued litigation until her death in 1464 , they subsequently returned to Wakehurst Place and seem to have lived in comparative peace for over forty years. While Richard (d. 1516) and Margaret (d. 1509) had no issue, Nicholas (d. 1509) and Elizabeth (d. after 1517) had a remarkable ten sons and eight daughters, as depicted on their (very crowded) funeral brass in Ardingly Church, Sussex. ${ }^{49}$ There is thus every sign that the narrative presented in their grandmother's petition was as fictitious as the story of Jane Boys's ravishment.

Naturally, the indictments and bills accusing men of ravishment constructed narratives in which the ravisher was cast as the villain. Paston himself may have accounted Edmund Wichingham and Robert Southwell-Jane's father and her intended husband - as the primary victims of Langstrother's villainy. At least that is what the text of his letter suggests, focusing as it does on the "gret oryble dede" of thwarting the well-laid plans of fathers and fathers' friends for particular marital alliances and strategies. But the narratives submitted for legal consideration do not follow that particular story line because the English laws regarding ravishment did not provide wronged fathers with a means of retrieving custody of a daughter who had consensually eloped. Instead, the legal narratives underscored the wrongs committed against a blameless Jane by the dastardly villain Langstrother. That story line was borrowed not only from other legal narratives but more broadly

${ }^{47}$ Goldberg, Communal Discord, 137-38.

${ }^{48}$ Elizabeth, late the wife of Richard Wakehurst, the elder, and Thomas Echyngham, Thomas Hoo, and John and William Gaynesford, esqrs., his feoffees v. John, Richard, and Nicholas Colepepir and Alexander Clyfford, ca. 1456-60, TNA: PRO C 1/26/304. The family relationship is not mentioned in the primary Chancery petition; it is, however, included in Richard Wakehurst's entry in J. S. Roskell, Linda Clark, and Carole Rawcliffe, The House of Commons, 1386-1421 (Stroud, 1992), 732. Mavis Mate, Danghters, Wives, and Widows after the Black Death: Women in Sussex, 1350-1535 (Woodbridge, 1998), 23, presents the alternate theory that Sir John Colepepir was married to the girls' aunt by marriage.

${ }^{49}$ Elizabeth, the late wife of Richard Wakehurst, the elder, and Thomas Echyngham, Thomas Hoo, and John and William Gaynesford, esqrs., his feoffees v. John, Richard, and Nicholas Colepepir and Alexander Clyfford, ca. 1456-60, TNA: PRO C 1/26/304; John Burke, Extinct and Dormant Baronetcies of England, Ireland, and Scotland, 2nd ed. (London, 1844), 145; "Ardingly, West Sussex," Culpepper Connections! The Culpepper Family History Site, http://gen.culpepper.com/archives/uk/ places/ardingly.htm. 
from depictions of ravishment in the popular literary genre of the romance and more generally in fifteenth-century chivalric culture.

Chivalric culture had become a crucial defining feature of gentility in England in the fifteenth century. ${ }^{50}$ As literary scholars, most importantly Kathryn Gravdal and Corinne Saunders, have pointed out, ravishment and rape scenarios were central to the chivalric romance genre: a man became a hero by rescuing a woman. ${ }^{51}$ Other kinds of chivalric literature-descriptions of the ceremonies for creating knights of chivalric orders, accounts of tournaments, heraldic treatises-repeated the tropes of fighting for fair ladies and the rescues effected by valorous knights of damsels in distress. John Paston's eldest son, Sir John (II), for instance, commissioned a miscellany manuscript that he called "my boke off knyghthod," made especially for him and apparently at his close direction..$^{52}$ Among the texts in Paston's book was a short French text describing the scenario for a planned pas d'armes to be held before the Duke of Burgundy in $1463 .^{53}$ Like contemporary professional wrestling contests, by the fifteenth century tournament events were often theatrically framed around a fictional narrative that provided a backstory to the conflict being enacted on the tournament ground, heightening the interest of both participants and spectators. ${ }^{54}$ These narratives were usually derived from Arthurian romance. ${ }^{55}$ The Burgundian pas d'armes in Paston's Boke derived its pretext from a letter written to the duke by a noble lady, in which she told of her oppression by a mighty knight of her neighborhood, who wished unjustly to deprive her of her inheritance through a forced marriage. The mighty knight gave the lady an ultimatum: she must accede to his advances, which had been repellent to her, or she must find a champion by 1 May of the following year to fight for her cause against him. Should the evil nobleman win, she must surrender both herself and her property to him; should her champion win, the evil noble would become the champion's vassal, and the lady would be free to bestow herself on anyone she chose (presumably, at least in the world of imagination, the champion who saved her)..$^{56}$ The pas d'armes before the Duke of Burgundy would welcome the greatest knights of Christendom to establish who would be the lady's champion. Such events would have been familiar to the late medieval English aristocracy

\footnotetext{
${ }^{50}$ Ruth Mazo Karras, From Boys to Men: Formations of Masculinity in Late Medieval Europe (Philadelphia, 2003), 20-66, esp. 47-57; Richard W. Kaeuper, Chivalry and Violence in Medieval Europe (Oxford, 1999), 209-15, 225-30; Jonathan Hughes, Arthurian Myths and Alchemy: The Kingship of Edward IV (Stroud, 2002), 174-89.

${ }^{51}$ Gravdal, Ravishing Maidens, 67, also 43-44; Saunders, "Matter of Consent," 105-24.

${ }^{52}$ Davis, Paston Letters, 1:516-18; G. A. Lester, Sir John Paston's "Grete Boke": A Descriptive Catalogue, with an Introduction, of British Library MS Lansdowne 285 (Cambridge, 1984). The account of a tournament between Lord Scales and the Bastard of Burgundy in Paston's Boke (see Lester, Grete Boke, 103-10) is included in Samuel Bentley, ed., Excerpta Historica; or, Illustrations of English History (London, 1831), 176-96.

${ }^{53}$ Lester, Grete Boke, 150-52.

${ }^{54}$ See Nicholas Sammond, ed., Steel Chair to the Head: The Pleasure and Pain of Professional Wrestling (Durham, NC, 2005), esp. the classic essay by Roland Barthes (originally published in 1957), "The World of Wrestling," 23-32.

${ }^{55}$ See Richard Barber and Juliet Barker, Tournaments: Jousts, Chivalry and Pageants in the Middle Ages (New York, 1989), 4, 8, 38-39, 46, 49-50, 108-25; Karras, From Boys, 30-31, 55.

${ }^{56}$ On rescued damsel as prize, see Saunders, "Matter of Consent," 114-15.
} 
through written accounts and through witnessing or hearing about such events as they were held throughout the fifteenth century.

If on the one hand the narrative in the indictment and Paston's letter casts Langstrother as the scheming villain from whom the damsel must be saved, on the other hand it is quite possible that Langstrother saw himself in the role of hero. For in the romance, ravishment could be framed as rescue rather than rape, as the liberation of a woman rather than her defilement. In such a narrative the man who forced a woman to marry contrary to her desires was the villain; the man who took her away was the hero. Although we know little about Robert Langstrother and nothing at all about his reading habits, as we have seen he had close family connections to the Hospitaller Order and thus was likely exposed to chivalric culture, both in its literary manifestations and through public events such as tournaments. ${ }^{57}$ Both he and Jane Boys may have regarded his abduction of her as a morally positive deed; it allowed Jane to escape a marriage to Richard Southwell that she did not desire and to bestow her widowed self where she wanted. As late medieval English widowed gentlewomen frequently had a more active role in choosing a second or third husband than their first, Jane could plausibly have thought it her due..$^{58}$

If our access to the thoughts and motivations of Jane Boys and Richard Langstrother are by necessity highly inferential, we are on firmer ground suggesting a connection between heroic ravishment and chivalric culture in another situation affecting the Paston family a generation later. This one involved John Paston's two older sons, Sir John Paston (whom we call John II) and his younger brother, also named John (and known to us as John III). Both John II and John III Paston themselves were immersed in chivalric culture. ${ }^{59}$ They wrote to one another and to their mother about the passionate interest they shared in tournaments, sometimes in copious detail, and John II himself participated in at least one tournament. ${ }^{60}$ John Paston II's library, which went to John III after his death, included a number of romances and other kinds of chivalric texts, including the Grete Boke discussed above. ${ }^{61}$

A short description of a ravishment scenario-a potential rather than an actual ravishment in this case-appears in a November 1474 letter written by John II to his younger brother John III. At the time of writing, both brothers were unmarried and actively wooing various prospects. John II wrote from London to his brother in Norwich, reporting a recent conversation he had had:

Item, as fore Stoctonys doghtre, she shall be weddyd in haste to Skeerene, as she tolde hyre-selffe to my sylkemayde whyche makyth parte off suche as she shall weere,

\footnotetext{
${ }^{57}$ On the association between the Hospitaller Order and chivalric culture, see Hughes, Arthurian Myths, 186-87.

${ }^{58}$ As Barbara Harris has commented, “unlike first-time aristocratic brides, peers' and knights' widows were able to marry for love. Most of them had, after all, been exposed to the culture of the court and romance literature that idealized such marriages" (English Aristocratic Women, 165).

${ }^{59}$ Richmond describes John II in particular as a "romantic" to whom the "heroic-chivalric" greatly appealed (Paston Family: Endings, 67).

${ }^{60}$ Davis, Paston Letters, 1:396, 535, 538-39.

${ }^{61}$ For an inventory of his books, see ibid., 1:516-18. He may have owned the Ellesmere Chaucer; see Richmond, Paston Family: Fastolf's Will, 29. Richmond discusses the reading tastes of John II and John III in Paston Family: Endings, 63-67.
} 
to whom she brake hyre harte and tolde hyre pat she sholde have hadde Master Paston, and my mayde wende it had been I pat she spake off; wyth moore, pat the same Master Paston kome where she was wyth $\mathrm{xx}$ men and wold have taken hyre aweye. I tolde my mayde bat she lyed off me, and pat I neuer spake wyth hyre in my lyff, nere pat i wolde not wedde hyre to have wyth hyre iij ml marke. ${ }^{62}$

This account, scattered in the letter among a number of other reports about marital possibilities, news ("the king came to this town on Wednesday"), and business matters, clearly had a backstory known to both writer and recipient, which we can only obliquely glimpse. While the silkmaid, not surprisingly, confused the two Paston brothers, both named John, we are left unsure whether the younger John did attempt to take away Stoughton's daughter or whether this was her fantasy. Whatever the case, Sir John was keen to dampen the gossip about any Master Paston and Stoughton's daughter, and he seems also to have been keen to assure his brother that he was well out of it: even an enormous dowry could not compensate for having to wed this woman. Stoughton's daughter was Agnes Stoughton, daughter of Thomas Stoughton, a prominent London fishmonger, royal servant, and member of Parliament. ${ }^{63}$ Despite her evident reluctance, Agnes married Robert Skern in the mid-1470s and had four children with him before his death in $1485 .^{64}$

If we look more closely at the passage, that phrase- "she shall be weddyd in haste to Skeerene"-implies another party in the passive verb: someone will soon wed her, in haste, to Skern. We do not know who the subject of the verb was, who was doing the wedding in this case-her father is the most logical suspectnor do we know why the marriage had to be in haste, although the usual explanation for hasty weddings certainly comes to mind. We need not assume pregnancy, however. Unmarried, of substantial fortune, and romantically yearning to be borne away by force from an unwanted marriage, Agnes presented a considerable temptation to someone like John Paston III.

John III's letters indicate that he well understood the value of appealing to a young woman's fantasies in courtship. John III, as a younger son, had to deploy as much personal magnetism as possible if he wanted to marry more successfully than his social station alone would warrant, and his letters suggest his strategic use of the charms of his person and manner in his pursuit of possible marriage partners. In one case, several months before his brother's report about Agnes Stoughton, John III wrote a love letter that was calculated to include the kind of subtle and suggestive appeals aimed at a young woman who read romances. ${ }^{65}$ The letter ends, in language both chivalric and suggestive: "And now farwell, myn owne fayir lady, and God geue yow good rest, for in feythe I trowe ye be in bed. Wretyn in my wey homward on Mary Maudeleyn Day at mydnyght." He makes references to the intended recipient being able to read English well, and romances (and romantic tales cloaked in moralistic guise in conduct books) were standard

\footnotetext{
${ }^{62}$ Davis, Paston Letters, 1:478-79.

${ }^{63}$ On Agnes's father Thomas Stoughton, see Josiah C. Wedgwood, History of Parliament, 1439-1509, 2 vols. (London, 1936-38), 2:817-18.

${ }^{64}$ Skern's death was dated 1 October 1485 in his inquisition postmortem. See TNA: PRO E 150/ 1065/5, calendared in Calendar of Inquisitions Post Mortem . . Henry VII, 3 vols. (London, 1898-1955), 3:571.

${ }^{65}$ Davis, Paston Letters, 1:590-92.
} 
reading fare for young women of the aristocracy and high bourgeoisie. The addressee was named Agnes, and it seems likely to us, although we admit we cannot find any positive proof, that she was Agnes Stoughton. ${ }^{66}$

John Paston III may have been a dashing wooer, but as a younger son he was not as advantageous a match for Agnes as Robert Skern, a Surrey gentleman with considerable estates and important political connections. ${ }^{67}$ The Skern marriage was a good marriage for Agnes in worldly terms, and it is easy to imagine that Thomas Stoughton, fishmonger, sought the cachet of an aristocratic marriage for his daughter. ${ }^{68}$ Agnes's reluctance, however, made such a situation ripe for consensual ravishment, and a hasty marriage was one way to put an end to the risk. If the medieval canon law of marriage - by which a woman could make a binding marriage without any reference to her father or family — created problems for fathers, it also provided weapons to combat those problems: by church law, a marriage, properly made, was permanent and indissoluble. Agnes's marriage to Skern neutralized the threat of her being abducted by an unsuitable suitor: the prize in such a ravishment was a marriage, and as a wedded woman she presented no temptation.

So much for the perspectives of her father and her potential abductor; what about Agnes herself? We see her only through John II's letter. By his account, she is longing to be rescued from her impending marriage- and she could best imagine such a rescue through the medium of ravishment. Someone must come and take her away; she herself cannot simply refuse the marriage (although of course by canon law, she could). If John III ravished her, the responsibility for disobeying her father's wishes would then be his. ${ }^{69}$ Through John II's report of her conversation with her silkmaid, we also glimpse a young woman who conceptualized her prospective marriage not only, or even mainly, as a political and economic alliance but as a personal and erotic union, understood through the framework of chivalric culture. She longs to be abducted by John Paston, to be seized and borne away by twenty men, rescued by the hero rather than married to the villain.

Agnes's brief description matches the standard narrative of ravishments in fif-

${ }^{66}$ Apart from the coincidence of the name Agnes (admittedly one of the most common female names of the period), John III calls his correspondent "the wedow of the Blak Freiris" (ibid., 1:592), while Agnes's parents' house in the parish of St. Nicholas Cole Abbey was near Blackfriars, and Thomas Stoughton, Agnes's father, judging by the bequests in his will (Thomas Stoughton, will, 1478, TNA: PRO PCC, Prob. 11/7, fols. 23r-23v), had a particular relationship with the Dominican friary. Colin Richmond provides an illuminating discussion of John Paston III's marital adventures, although he misidentifies "Stocton's daughter." Richmond, Paston Family: Endings, 41-55, esp. 45-48.

${ }^{67}$ Skern came into his lands in Kingston and elsewhere in Surrey upon his father's death in 1464, at which time he was a law student at the Inns (William Skern Sr., will, 1464, TNA: PRO PCC, Prob. $11 / 5$, fols. $31 \mathrm{rv}$ ). Despite his youth, Skern evidently soon after this became a trusted member of the equally young Earl of Oxford's household, as by 1467 the Paston letters record him acting as Oxford's agent in discussions with the archbishop of York (Davis, Paston Letters, 2:383). While he served Edward IV in the later years of his reign, he fought for Henry Tudor at Bosworth, for which he was rewarded. He died, however, within weeks of Bosworth. Calendar of the Patent Rolls . . 1467-77 (London, 1900), 246, 248; Calendar of the Patent Rolls . . . 1476-85 (London, 1901), 23, 24, 144; Calendar of the Patent Rolls . . . 1485-94 (London, 1914), 36-37; TNA: PRO E 150/1065/5, calendared in Calendar of Inqusitions Post Mortem . . . Henry VII, 3:571.

${ }^{68}$ In comparison, e.g., Agnes's sister Appoline married John Devet, a fishmonger, who did not reach higher than middling status as a London merchant. Thomas Stoughton, will, 1478, TNA: PRO PCC Prob. 11/7, fols. 23r-23v; John Devet, will, 1483, London, Guildhall Library, MS 9171/6, fol. 373v.

${ }^{69}$ See Sylvester, Medieval Romance, 49, 63-65. 
teenth-century court records - the ravisher, accompanied by a large party of armed men, seizes the victim from her father's home. Had John Paston III chosen to fulfill her fantasy, he might well have followed the narrative. For ravishment narratives could find a place not only in romances and in the membranes of court rolls but also in the unfolding of real instances of ravishment. Ravishers and their victims - whether complicit or not-may well have followed a kind of script, whether consciously or unconsciously. Kathryn Gravdal has suggested that fictional texts - the romance, the pastourelle - "offer men and women the words to circumscribe or describe and perhaps institutionalize experiences that are difficult to comprehend, whether painful or pleasurable." ${ }^{70}$ Gravdal's insight here can be taken a step further. For her, the experience of ravishment is anterior to the establishment of meaning, raw in a way. We might instead consider that the meaning of experience is constituted coterminously with the experience itself or indeed even before the experience. The constellation of culturally available models shapes how an event is understood as it is anticipated, as it happens, and as it is remembered and continues to be rendered meaningful afterward.

Both legal and literary narratives were powerful - if by no means the onlyparticipants in this feedback loop of the establishment of meaning. Particularly vivid examples of the interplay of courtroom dynamics, law and legal definitions, and literary narratives in the production of meaning from such narratives come from scholarship on the early modern witchcraft prosecutions. As scholars such as Carlo Ginzburg, Lyndal Roper, and Malcolm Gaskill have argued - each in a somewhat different way - the understanding of a relationship, event, or experience as witchcraft was shaped by cultural depictions (in books, pamphlets, images, and the elusive spoken word) and by the theater of the courtroom itself, which both was embedded in that culture and in turn helped to produce it. ${ }^{71}$ As Roper in particular has argued, this encounter takes place in the unconscious; if at first human psychology seems "so fundamental as to be scarcely historical at all," we can only approach understanding the early modern "witch craze" by positing interplay between unconscious motivations and culture. ${ }^{72}$ Similarly, the meanings of ravishment and the many different ways it was experienced and understood were derived from complex interactions among fifteenth-century conceptions of chivalry, law in letter and practice, the gendered understandings of late medieval aristocratic marriage patterns, and unconscious motivations that were shaped (if by no means solely determined) by all of these.

This may help us comprehend the possibility that, as Dunn proposes, the Boys ravishment was a staged event in which Jane Boys was complicit. Its apparent similarity to other contemporary cases could be due to the expectations and preconceptions of its participants and witnesses. Its theatricality-for such a ravishment, if staged, clearly followed a script that all involved would have recognizedmay have served the same kinds of purposes we have proposed for Agnes Stough-

\footnotetext{
${ }^{70}$ Gravdal, Ravishing Maidens, 140.

${ }^{71}$ Carlo Ginzburg, The Night Battles: Witchcraft and Agrarian Cults in the Sixteenth and Seventeenth Centuries, trans. John Tedeschi and Anne Tedeschi (Baltimore, 1983); Lyndal Roper, Witch Craze: Terror and Fantasy in Baroque Germany (New Haven, CT, 2004); Gaskill, Crime and Mentalities, esp. 222-41; and Malcolm Gaskill, Witchfinders: A Seventeenth-Century English Tragedy (Cambridge, MA, 2005).

${ }^{72}$ Roper, Witch Craze, $\mathrm{x}-\mathrm{xi}$.
} 
ton's fantasy of ravishment: that Jane was reluctant to explicitly oppose her father's plans for her remarriage and could do so only by (initially, at least) pretending that she was being ravished. A staging would have displaced responsibility for the unsanctioned marital union. It could also serve the function of simultaneously displacing responsibility for the unsanctioned eroticism implicit in the ravishment and heightening that eroticism.

Throughout this article we have used the term "ravishment" rather than "abduction" to talk about the taking away of elite women for the purposes of marriage, precisely because the word for us retains its original sexual implication. Some modern scholars, most recently Henry Kelly, have sought to distinguish between, on the one hand, abduction, a nonsexual kidnapping that was frequently an elopement rather than forcible taking away, and, on the other hand, forcible coition, a sexual crime. Abductions in this scenario were about property and marriage but stripped of any sexual connotation; rape as forcible coition, a felony distinct from abduction, was another thing altogether. ${ }^{73}$ It is important to recognize that the felony appeal of rape-however rarely successfully prosecuted in the late Middle Ages - dealt with a somewhat different problem from ravishment. But it is also important to recognize that ravishment frequently had sexual implications, in particular in cases in which a marriage was the end for which abduction was the means (as distinct from child-custody disputes, for instance).

Several points need to be taken into account in thinking about these issues. One involves marriage: even for the elite, whose unions were about money, power, and politics, marriage was also about sex, about use of a woman's body as well as her lands. ${ }^{74}$ The ravishment of a woman for the purposes of marriage was thus also about taking her away to have sex with her. If many ravishment complaints, including the legal arguments concerning Jane Boys's ravishment, omit any explicit discussion of sexual congress, this is, we would argue, both because it did not need to be said-such congress or at least its potential was to be assumed (indeed was contained within the word "ravish") when virile, sword-wielding man seized nubile woman - and at the same time because it could not be said, at least in a case in which a marriage to another man might be salvaged.

Ravishment, by virtue of its illegality, was a risky act for a man to undertake. Although he might succeed in carrying away a bride, he also faced considerable legal tribulations and the possibility of imprisonment or financial penalties. Indeed, it may be that in demonstrating his willingness to face this risk, to suffer such penalties, he was at least partly also indicating his passion for his beloved and that she in turn may have been moved by the evident peril of the act and by the strength of his ardor. A willingness to suffer for love, to place oneself and one's financial future at risk, could also act to heighten desire. Ravishments, as their role in romance fiction suggests, were thus a site of sexuality and indeed of the shaping of heterosexual eroticism.

It is a troubling eroticism for twenty-first-century scholars, ambiguous as it is regarding the woman's willingness to be taken. Louise Sylvester has recently argued that for women in medieval romances, the only appropriate answer to a sexual advance was no-for women resisting a sexual request was "a cultural require-

\footnotetext{
${ }^{73}$ Kelly, "Statutes," 361-419, esp. 398-400.

${ }^{74}$ On this point see Goldberg, Communal Discord, 122-25.
} 
ment." 75 Garthine Walker, moreover, has pointed out that the ambiguities of women's consent in defining ravishment were part of a larger conceptualization of sexual intercourse in general that tended to efface women's consent. Grammatically and in a larger sense conceptually, women in premodern England and Wales had sex done to them; even in a consensual sexual situation, they submitted to advances or surrendered. Demonstrating or even conceptualizing resistance to unwanted advances was very difficult when resistance looked very much like the coy reluctance women were expected to demonstrate even in consensual situations. ${ }^{76}$ Male advance, female retreat: gendered expectations become encoded in sex and heterosexual desire. ${ }^{77}$

The laws concerning ravishment, which dealt ambiguously with women's consent; chivalric culture and the rescue narrative, through which a woman could only escape an undesirable situation through rescue by a heroic male; and a culture in which women's agency, especially regarding her hand and her body, was best exercised by proxy: how did these aspects of late medieval elite culture shape sexual desire among the late medieval English elite, especially among its women? If the place of women's consent in sexual encounters, not to mention ravishments, was so entirely ambiguous in law, in literary and chivalric culture, in more generalized gendered expectations of women's behavior, we must ask how that shaped women's experience and desire, how it might have created a place for "ravishment fantasies," as in the story about Agnes Stoughton told by Sir John Paston. ${ }^{78}$ We must also in turn ask, if perhaps we cannot answer, how desire itself, in its many manifestations-for we are by no means arguing here for a singular but rather multiple desires-shaped law, literature, and in general the meaning of experiences.

${ }^{75}$ Sylvester, Medieval Romance, chap. 1 (quotation at 38).

${ }^{76}$ Garthine Walker, "Rereading Rape and Sexual Violence in Early Modern England," Gender and History 10, no. 1 (1998): 6, and "'Strange Kind of Stealing': Abduction in Early Modern Wales," in Women and Gender in Early Modern Wales, ed. Michael Roberts and Simon Clarke (Cardiff, 2000), $51,63-64$.

${ }_{77}$ This argument for the shaping of desire owes much to the large literature on the history of sexualities in its understanding of how desires are understood and shaped (even sometimes generated) by culture; e.g. (but by no means exhaustively), Michel Foucault, The History of Sexuality, 3 vols. (New York, 1990); David M. Halperin, "Forgetting Foucault," Representations, no. 63 (Summer 1998): 93-120; George Chauncey, Gay New York: Gender, Urban Culture, and the Makings of the Gay Male World, 1890-1940 (New York, 1994); John Howard, Men Like That: A Southern Queer History (Chicago, 1999); Anne Fausto-Sterling, Sexing the Body: Gender, Politics, and the Construction of Sexuality (New York, 2000); Craig A. Williams, Roman Homosexuality: Ideologies of Masculinity in Classical Antiquity (New York, 1999).

${ }^{78}$ See esp. Sylvester, Medieval Romance, 39-41, 43. 